\title{
The right to life
}

\section{Author's abstract}

For much of human history the idea of a right to life has not seemed self-evident. The credibility of the idea appears to depend on a particular kind of intuition concerning the nature of the world. In this paper, the kind of intuition involved is related to the idea of a covenant, illustrated by that of marriage. The paper concludes by suggesting that talk about responsibilities may be more fruitful than talk about rights.

Although dependent on older ideas, the 'right to life' is a modern formulation. Its classical, if not its first appearance is in the American Declaration of Independence in 1776 , which holds

'these truths to be self-evident, that all men are created equal, that they are endowed by the Creator with certain inalienable rights, that among these are Life, Liberty and the pursuit of Happiness'

In a recent play, an Italian-American Catholic mother tells her son, 'Son, don't pursue happiness, it will only make you miserable'. For much of human history, I suspect, an equally pessimistic conclusion might have been reached by anyone seeking evidence for the supposedly self-evident right to life.

To illustrate this point, let me retell a story, which is at least 1500 years older than Homer and one of the earliest human tragedies. The story is the Epic of Gilgamesh, which dates from the 3 rd millenium BC, but was only rediscovered last century. In barest outline, it goes like this.

Gilgamesh, the young king of Uruk on the Euphrates, is superior to all other men in strength and beauty, but also in lust, so that no-one's wife or daughter is safe. To control him, the citizens send a harlot to seduce, civilise and bring back Enkidu, the innocent wild man from the hills. She succeeds; and arriving in the city Enkidu wrestles with Gilgamesh, is recognised as his equal and becomes his friend. Together they set out to win fame. In the forest they meet and subdue its guardian, the giant Humbaba; and although Gilgamesh is willing to spare the giant's life, he is persuaded by Enkidu to kill him. Returning in glory and splendour Gilgamesh is sought as hcr lover by the goddess Ishtar; but he declines her offer, reminding the goddess that one of her former lovers is now a bird with a broken wing, a second a hunted wolf and a third a blind mole. Furious at these home truths, Ishtar releases the terrible bull of heaven to create destruction; but Gilgamesh and Enkidu kill it, and Enkidu, with appropriate insults, throws the bull's right thigh in Ishtar's face. All this hubris however is too much for the gods, whop decide that one of the heroes must die; and because Gilgamesh has a powerful god for his protector; Enkidu is chosen.

The first part of the epic ends with Gilgameslg mourning for Enkidu,

'the axe at my side

My hand's strength, the sword in my belt, The shield before me,

A glorious robe, my fairest ornament;

An evil fate has robbed me' (I).

Bowed down with grief and oppressed by hige knowledge of death, Gilgamesh sets out once aggip from Uruk, in search no longer of fame, butoop Enkidu and everlasting life. To achieve this, he tries to find Utnapishtim his ancestor, who surviveद the flood and whom the gods took to live for evef at the mouth of the rivers. After long wanderings in the wilderness and an interminable journey througlo the darkness under the mountain of the sun? Gilgamesh arrives at a garden by the shores of the Ocean. There he meets the young woman: of the vine, the maker of wine, who tells him that he will never find the life he looks for, and that h\& should eat, dance and be merry. But Gilgames rejects her advice, and persuades the ferryman to take him across the Ocean to the land of Dilmum where Utnapishtim his immortal ancestor lives, When they meet however, Utnapishtim is no more encouraging than the woman of the vine; he onl $\$$ escaped the flood, he explains to Gilgamesh, be cause a friendly god warned him to build a boat. and it was only because the gods were so appalled and flustered at the way they had let the flood ger out of hand, that they allowed him to become immortal. Since no such circumstances obtain ix Gilgamesh's case, Utnapishtim tries to reconcile hinf to his mortality and he proves his point by chal $\$$ lenging Gilgamesh to keep awake for six days and seven nights, and seeing the sorrowful hero fail to do this.

Gilgamesh thus prepares to go home to Uruk an $\$$ death. But just as he is leaving, Utnapishtim? 
prompted by his wife, reveals to Gilgamesh where to find an underwater plant which will renew his youth. Finding it, Gilgamesh hopefully begins his homeward journey, carrying the plant which he plans to share with all the old men of Uruk. On the way, however, while Gilgamesh is bathing, a serpent rises from the pool, snatches the plant and disappears, sloughing its skin as it goes. Nothing then is left for Gilgamesh but to return to Uruk and to die; and in a final lament, the meaning of his life is explained:

'O Gilgamesh ... you were given the kingship, such was your destiny, everlasting life was not your destiny' (2).

Now while modern commentators have made a number of interesting points about the mythology of the Epic of Gilgamesh, one of the most significant for our present purpose is the suggestion (3) that, in the Epic, kingship and everlasting life are seen as mutually exclusive alternatives. The point is doubly interesting if we link it up with another mythological tale, which comes from roughly the same part of the world, that of Adam and Eve in the Garden of Eden. In the Genesis story, as well as another serpent, and later of course a parallel flood, there is the tale of the two trees: the tree of knowledge from which Adam and Eve ate, and the tree of life from which they did not, because God did not want them to live forever. And the similarity between the two stories is strengthened of course, when we remember that kingship and knowledge are both forms of power.

\section{Human intuition}

What I want to suggest here then is that the Epic of Gilgamesh and the story of Adam and Eve can both be seen as expressing the very primitive and basic human intuition, first that knowledge and power on the one hand and everlasting life on the other are mutually exclusive alternatives; and second that, as far as man is concerned, the choice between these alternatives has been made, irrevocably and long ago, in favour of knowledge and power. This intuition, I admit, may not seem at first sight to have much relevance to the discussion of human rights, and in particular the right to life, today. But if the intuition really is a basic one, a perennial as well as primitive insight into the human condition, it has two implications which, even today perhaps, are worth considering.

The first of these implications, if the intuition is sound, is that human beings, as human beings, may well have no right to life at all. If the Gilgamesh and Genesis stories really do reflect the true human condition, there is no ground for claiming this right. The immediate objection to this, of course, is that the two stories are concerned with everlasting life, and not the kind of life the right to life asserts.
But the point to notice about the stories is that while they are concerned with everlasting life, they are not concerned with life after death. In the Mesopotamian and Old Testament background to these stories, as in that of the Homeric epics, life beyond death was not thought desirable. Before his death, Enkidu, for example, has a vision of where he is going: 'the house where people sit in darkness: dust is their food and clay their meat' (4). In the Old Testament the Psalmist has a similar vision of the dead forsaken in the pit of Sheol and forgotten by God (5); and in the same vein there is the scene in the Iliad, when Patroclus' spirit 'vanished like a wisp of smoke and went gibbering underground', and Achilles cries 'Ah then, it is true that something of us does survive, even in the Halls of Hades, but with no intellect at all, only the ghost and semblance of a man' (6).

Against the background of this ancient view of the undesirability of life after death then, the comparison between what Gilgamesh wanted, what Adam and Eve were denied and what the modern right to life claims, may seem less forced. In each case what is involved is something at least as close to quality of life as to quantity of life. It cannot be denied, of course, that quantity is also involved in the ancient examples; but the essential common factor is not length but desirability. What the ancient and modern examples alike are about, I think, is thus some sort of guarantee of a desirable human existence. But it is this guarantee that the ancient intuition says we cannot have; and if the intuition is sound, it seems to deny the modern right to life just as much as the ancient aspiration for everlasting life.

\section{The power of knowledge}

It seems from this then that the right to life is not self-evident at all. And if this first implication of the primitive intuition is not very encouraging, nor is the second. The second implication, given again the soundness of the primitive intuition, concerns what we are left with instead of everlasting life or the guarantee of a desirable existence, namely the power of knowledge; and the point about human knowledge and human power is its ambiguity. The point in relation to power is made in the Gilgamesh Epic, which emphasises how easily the power of kingship can be abused. In the story of Adam and Eve the point is made even more profoundly in relation to knowledge. The tree whose fruit they ate is the tree of knowledge of good and evil; and seeing that they have eaten it, God says that they have 'become as one of us', become, that is, as one of the gods. Here again the primitive mythological insight is uncannily accurate in its diagnosis: what it observes, in effect, is something which it took many philosophers until quite recently to grasp- 
that is, the fundamental relativity of human knowledge; or, to put it another way, the fact that knowledge is something man creates. In mythological terms man becomes like one of the gods because he also is able to decide what is good and evil. In what perhaps are more familiar terms, the myth is reflected in the process of thinking through any moral dilemma we are deeply concerned with and determined to sort out. Beginning, that is, from the black and white of conventional moralities, we move through the infinite gradations of grey revealed by deeper questioning, till the deepest questions of all bring us, as Socrates insisted they must, to the ultimate knowledge of our own ignorance. From this impasse there is no escape, except by the unaided exercise of the will, its refusal to rest in total ignorance and relativity, its insistence that there must be some standards, however arbitrary. The end of our ethical enquiry, in other words, is not truth (except the truth of our ignorance) but the godlike act of asserting for ourselves what is good and evil.

The primitive mythological intuition expressed in the two stories of Gilgamesh and the Garden of Eden then, if it is correct, implies not only that the right to life is not self-evident but also that in asserting it we are making what looks like a rather arbitrary decision about what to believe. Something of the stark pessimism which colours this insight, learned by Gilgamesh on the shores of the Ocean, is reflected, on a more modern shore, in Arnold's Dover Beach

'. . the world, which seems

To lie before us like a land of dreams,

So various, so beautiful, so new,

Hath really neither joy, nor love, nor light,

Nor certitude, nor peace, nor help for pain:

And we are here as on a darkling plain

Swept by confused alarms of struggle and fight,

Where ignorant armies clash by night' (7).

Now if, as I keep on saying, the primitive intuition is correct, and if the Gilgamesh and Garden of Eden mythology express the essentials of the human condition, and if Arnold's pessimistic views of the modern world is justified, how, we might ask ourselves, were the American Founding Fathers so naive as to believe that the right to life was a self-evident truth ? Dismissing as unworthy the thought that it was because they were Americans, a clue, I think, can be found in the same poem of Arnold's.

What I quoted a moment ago was not the whole of the last verse of Dover Beach. The verse, which follows his elegy on the retreating sea of faith, in fact begins

'Ah love, let us be true

To one another, for the world, which seems

To lie before us like a land of dreams ...'

Now these words 'Ah love, let us be true/To one another' do not in the context of Dover Beach itself do much to relieve the poem's pessimistic tone But if, in the poem generally, we can detect some $=$ thing of the primitive intuition I have been speakin about so far, we can also detect, in these words. another intuition, almost and perhaps equally as primitive, which may well alter the whole come plexion of our understanding of the right to life.

'Ah love, let us be true/To one another'. The intuition behind these words, I think we can sa without stretching the sense too much, is tho primitive and perennial intuition of those who seek, in a scene of desolation, to make a covenant wit? another living being. The point of a covenant is the exchange of promises, often in symbolic form which binds the covenanting parties together, givin their existence a framework and shaping theip subsequent lives. A covenant is thus at once more voluntary, more unconditional and more permanent than a contract. In Dover Beach, the covenanit offered takes what is perhaps its most familiar form the exchange of promises between a man and at woman, if not in marriage itself, then in somethinf very like it. This familiar form of covenant, prosaie as often as romantic, provides a framework of security in an insecure world. If it is kept, and it ma be kept in a variety of ways, it provides a shelter from the elcments and a kind of warmth, howerefs minimal, in which human personality is allowed an opportunity to unfold its sometimes glorigur and sometimes grotesque potential.

Much, or little then, can be gained from this familiar, man-woman form of covenant; and what is gained depends on the endowments of the parties themselves, and on the determination and in genuity with which the covenant is kept. In keeping it, however, the aim is not really to gain anything at all: if it were, it would not be a covenant but $\frac{-6}{6}$ contract. The aim is not even security, because that after all can only be a by-product which, if directl⿸户 pursued (like happiness) only makes you miserablês Indeed what the aim of marriage actually is (despite the various ecclesiastical formulations of it) is no easy to say: it varies from person to person, from time to time, and in the end can only be intere preted perhaps, in the terms already suggested, as a primitive and perennial intuition into the nature of the human condition and its potential.

\section{Covenants}

But how does all this talk about marriage alter the complexion of our understanding of the right to life? The point here, I think, is that marriage or similat man-woman relationships, provide only on $\$$ example of the kind of covenant human beings cap make. There is, however, another kind of context in which the same, or at least a very closely relate $\$$ primitive intuition has been expressed, and wit important historical consequences. 
Now the expression I have in mind here, to which the words 'Ah love, let us be true to one another' are not entirely inappropriate, is the one whose most familiar form, for Europeans at least, appears in Old Testament Mythology, but at a rather later stage than the Garden of Eden story. Its nature, I think, can be best illustrated by comparing the story of the flood in the Epic of Gilgamesh with its equivalent in the Book of Genesis.

In the Gilgamesh Epic, the story of the flood, as I mentioned earlier, is told by Utnapishtim its survivor, to reconcile Gilgamesh to his mortality. The story is similar in so many respects that a common origin, whether literary or meteorological, seems likely. Nevertheless there are some significant differences, not least about the cause of the flood and its consequences. The cause in Genesis is the wickedness of man and his evil thoughts which grieve God and make him repent man's creation. In the Epic, by contrast, the problem is less a matter of wickedness than of noise abatement: as Enlil, the chief executive god tells the others in council: "The uproar of mankind is intolerable and sleep is no longer possible by reason of the babel" ': and so, as the Epic succinctly puts it, 'the gods agreed to exterminate mankind' (8).

The story of the flood itself, the building of the boat, the rise and fall of the waters, the grounding of the boat on a mountain, the despatch of birds in search of land, is all substantially similar, although the dramatic effects in Gilgamesh are, perhaps predictably, much more impressive than in Genesis. But in the mythological context, the contrast between Jehovah's moral seriousness and the capriciousness of the Babylonian gods is again apparent. When Utnapishtim the survivor, standing on the mountain, makes a sacrifice and pours out a libation, the gods, according to the Epic, smell the sweet savour and gather 'like flies over the sacrifice' (9). A flustered and fallible lot, nervously recovering from terror at the effects of their own power, they are able, in compensation to mankind, only to offer immortality to Utnapishtim. But nothing in effect has changed; the gods have learned nothing and forgotten nothing. Their thoughts, such as they are, are voiced by Ishtar, the grim goddess of love and war who was later to proposition Gilgamesh. Ishtar fingers her lapis lazuli necklace and declares 'by the lapis lazuli round my neck I shall remember these days as I remember the jewels of my throat' (IO). One is not sure whether this is a threat or a promise.

In Genesis, by contrast, the story ends differently. Noah, the Utnapishtim figure, makes a sacrifice, and God smells its sweet savour. But God is neither flustered, nor does he offer Noah everlasting life. What he does offer is a covenant, which is clearly not a threat, but the promise, that 'while the earth remaineth, seedtime and harvest, and cold and heat, and summer and winter, and day and night shall not cease' (I0) and the token of the covenant is the rainbow sign.

Now in introducing the rainbow covenant, I don't want to claim, at least not here, that the Old Testament or later Christian view of man's relation to nature is necessarily true, nor that it is the only hopeful one. All I want to say, simply, is that the rainbow myth expresses a primitive intuition which is, I believe, at least as basic as the pessimistic one I discussed earlier. This intuition is expressed, in human terms, by man addressing something, he may not know what, which transcends him, with words which, as I have said, are not entirely different from these of Arnold to his girl: 'Ah love, let us be true to one another'. Here, of course, what man is addressing is not physically present; and so unlike marriage, it is a covenant with the unknown. But marriage too, in one sense is a covenant with the unknown, at least if you take human personality and the accidents of life seriously; and so the comparison is not entirely inept.

\section{Contemporary relevance}

Again however, what has all this to do with the right to life in contemporary discussion ? The answer is a fairly straightforward historical one. The influence of this kind of intuition and mythology was developed through the history of Judaism and Christianity, and no doubt elsewhere as well: the Pythagorean origins of the Hippocratic Oath, for example, which forbid abortion and euthanasia, suggest similar influences. These influences, in turn, led people to believe, contrary to much evidence in nature, and contrary to their own more pessimistic intuitions, that human life was valued and valuable in absolute terms. Thus, through the covenant-type relationships their intuitions compelled them to propose to or accept from the unknown, many people found just enough in their experience to believe that these intuitions were true, and to go on willing that they should be. So, when the American Founding Fathers claimed that the right to life was self-evident, they were not stating the obvious, but backing a hunch: a hunch for which history gave them just the barest margin of evidence to believe that it might be correct.

In Jefferson's original draft of the American Declaration, the point is made in a more philosophical way, when he writes that the right to 'the preservation of life ... derives' from the 'sacred and undeniable' truth of an equal creation (12). The demands of rhetoric changed this formulation, just as the demands of politics (to appease the South) deleted Jefferson's original anti-slavery passages from the Declaration. Thus the right to life passed into modern usage, and is widely employed today, particularly in arguments about abortion and euthanasia. But considering that such a right, logically I think as well as historically, can be argued 
for only in terms of the presuppositions which it derives from, which are themselves arguable, I am not sure that the simple assertion of it is really very helpful now, however useful it may have been in political arguments against George III.

In particular, considering the historical significance of the covenant idea, I am not really at all sure whether contemporary talk about human rights is not leading us up a particularly unconstructive blind alley. If the covenant way of thinking does express the more hopeful intuition about humanity, and if this kind of covenant is anything like the one Arnold proposed to his girl, the implications of talk about rights are not very cheering. In marriage certainly people only start to talk about rights when things go wrong, because human ingenuity can almost always find some rationalisation for a grievance. In marriage at any rate, matters can only be resolved and improved when a sense of the ridiculous or an expression of affection intervenes. And while I realise that the dilemmas of politics and of medical ethics are different in many ways from those of marriage, I really do wonder if the human interests, complex and individualised, of all the actors and sufferers concerned would not be better served by pushing the question of rights rather more into the background, and thinking of these problems more in terms of our responsibilities.
Thinking in terms of responsibilities, of cours, unties no Gordian knots : nor of itself, will it supphy the sense of community without which many contemporary moral dilemmas will remain unsolved. Nevertheless, talking in terms of respohsibilities, those of patients as well as doctors, ours $\overrightarrow{\mathrm{f}} \mathrm{s}$ well as theirs, does, I believe, offer a more generogs, humane and hopeful starting point for action then much of the present talk about human rights.

\section{References}

$\frac{}{0}$
$\frac{0}{8}$
$\frac{1}{2}$
$\infty$
$\infty$

(I) Sanders N K. translator. The Epic of Gilgamesh. Harmondsworth: Penguin Classics, 1972: 94.

(2) Ibid p 118

(3) Dunne J S. The City of Gods. London: Sheldogn Press, 1974: Ch I.

(4) Sanders N K. Op cit. p 92.

(5) Psalm 88: 4-5.

(6) Homer. The Iliad. Rieu E V. translator. Harmon $\overrightarrow{d 8}-$ worth: Penguin Classics, 1950: 414f.

(7) The Poems of Matthew Arnold 1840-1867. Londo Oxford University Press, 1913: 40If.

(8) Sanders N K. Op cit. p ro8.

(9) Ibid p II I.

(IO) Ibid Introduction p 42.

(II) Genesis 10: 22.

(12) Oxford Dictionary of Quotations. London: Oxfơd University Press, 1975; 2nd edn: 268. 